\title{
Economic, Political, Social Factor of Corruption in the Slovak Republic
}

\author{
$\overline{\text { Beáta Mikušová Meričková }{ }^{1} \text {, Andrea Bašteková }{ }^{2} \text {, Jan Stejskal }{ }^{3} \text {, Bernard Pekár }{ }^{4}}$
}

\begin{abstract}
Interdisciplinary definitions of corruption perceive corrupt actions as contrary to legal and ethical standards affecting the public interest, perpetrated by a person in public office. The main goal of the study is to identify the factors of corrupt acts in the public sector stemming from the economic, political, cultural and social environments in the Slovak Republic. Through the Delphi method we verify the relevance of economic, political and cultural-social factors of corrupt acts in the public sector defined in the theoretical framework of this issue. The Delphi method was used under the following conditions: the anonymity of experts, feedback control and statistical determination of a consensus of experts. Expert evaluation of the factors underlying corrupt behaviour in the public sector enabled us not only to detect the overall relevance of the factors, but also to identify areas where corruption in the public sector is most widespread, according to experts. We can state that the most problematic areas include the judiciary and the police.
\end{abstract}

\section{Key words:}

Corruption definition, public sector, Delphi method, economic factor of corruption, political factor of corruption, social factor of corruption.

1 Professor, Department of Public Economics and Regional Development, Matej Bel University, Banska Bystrica, Slovakia.

$2 \mathrm{PhD}$, Department of Public Economics and Regional Development, Matej Bel University, Banska Bystrica, Slovakia.

3 Associate Professor, Faculty of Economics and Administration, Institute of Economics Sciences, University of Pardubice, Pardubice, Czech Republic.

4 Associate Professor, Faculty of Law, Comenius University, Bratislava, Slovakia. 


\section{Introduction}

The interdisciplinary character of corruption allows for a definition of it from different perspectives. Despite that, though, it is clear that "social science in itself does not provide a full explanation of corrupt behaviour" (Beblavý 2007, 698). The legal definition of corruption is found in the Criminal Code. By law, corruption is defined through its forms, whereby the criminal offense of corruption consists of accepting a bribe, bribery, indirect corruption and electoral corruption. The criterion approach to the definition of corruption is based on a purely legalistic point of view and thus perceives corruption as a conduct that violates applicable laws (a positive approach to the definition of corruption - Staroňová and Sičáková-Beblavá 2009, 12). In the case of violation of laws by persons in public offices, we are discussing deviant action, "which is not in accordance with the standards set for holding public office because of the preference for private benefit (relating to individual persons, families and kindred groups, political or other organizations) in the form of financial (material) position or profit" (Vörös 2011, 2). The prescriptive approach to the definition of corruption declares a breach of ethical standards in order to give priority to one's own interests above the public interest (Staroňová and Sičáková-Beblavá 2009).

The concept of the public interest arises from two major lines of philosophical thought, utilitarianism and contractarianism. Utilitarianism proposes that the public interest is the increase of social well-being and the question of fairness is seen simply as a matter of the maximization of collective utility (Mill 2001). The contractarian position proposes the application of the principle of distributive equity, trying to go beyond the liberal principle of ensuring equality of opportunity (McCord 1999). These theoretical conceptions of the public interest allow us to consider it an ethical, non-subjective concept which serves the entire community.

Public interest can be seen as an economic concept (Apgar and Brown 1987; Bailey 1987; Bower 1974; Buchanan 1996; Hayek 1994; Nemec 1998) and Vörös (2011), Beblavý (2007) as well as Hegemann and Berumen (2011) see corrupt action as an economic activity that can be described according to the basic rules of the market economy (individuality of actions, consciousness of the benefits and costs of such actions in order to maximize one's own advantage).

In addition to the definition of corruption from the perspective of law and economics, it may be defined by the parameters of political science (Štička et al. 2005; Bardhan 1997; Nye 1967; Heidenheimer et al. 1989; Staroňová and Malíková 2007) and sociology (Graeff and Mehlkop 2003, Cartier-Bresson 1997). Interdisciplinary definitions of corruption perceive corrupt actions as contrary to legal and ethical standards affecting the public interest, perpetrated by a person in public office.

In seeking to assess the impact of various factors of corruption in the public sector we cannot avoid the requirement for corruption measurability. In the litera- 
ture we meet with an estimate of corruption, with a perception of corruption, which is subjective. The question is whether we can get the value of objective measurement. In measurements, it is important to decide on what will be included in measurement processes and solve the problem of how to measure something that may take place in a hidden form. Indeed, these facts make the measurement difficult and set barriers for obtaining the objective information about the corruption behaviour in the public sector. The "hard" data may not adequately capture the true measure of the prevalence of corruption in the public sector. Volejníková (2007) provides an example of official police statistics, which talks about cleared offenses related to corruption. These statistics depend on the ability of authorities, on their ability to detect and prove the corrupt behaviour. Therefore, the "hard data" from statistics cannot be objectively representative of the prevalence of corruption. In academia and also practice we can very frequently meet various indexes based largely on subjective perceptions and evaluations of experts (typically international institutions, such as the World Bank, Political Risk Services Group, World Economic Forum; Stampford et al. 2006; Volejniková 2007; Jain 2001).

The causes underlying the incidence of corruption in the public sector result from the economic, political, cultural and social environments. Correlation between the monopoly market environment and extensive state intervention regulating the environment and corruption is confirmed by several studies (Kligaard 1998; Broadman and Recanatini 1999; Djankov et al. 2002; Treisman 1999; Lambsdorff et al. 2000; Ades and di Tella 1999). Another economic factor in the growth of corruption is the size of the public sector (Elliot 1997; Montinola and Jackman 2002; Graeff and Mehlkop 2003) and the low salaries of public-sector employees (Tanzi 1998; Sičáková-Beblavá and Beblavý, 2007; Ochrana and Maaytová 2012).

Several authors have reported a link between the growth of corruption in the public sector and the low levels of economic freedom (Chaufen 2012; Swaleheen and Stansel 2007). A factor of corruption in the public sector arising from the policy environment is a measure of democracy. Many studies confirm that a high level of democracy reduces the risk of corrupt behaviour (Treisman 1999; Rose-Ackerman 2006; Gerring and Thacker 2004; Ledrman et al. 2001; Panizza 2001).

Decentralization as part of the democratization process, by contrast, has a negative impact in terms of containment of corruption in the public sector. Research into the relationship between political decentralization and corruption concluded that the incidence of receiving and offering bribes increased with the number of different levels of government (Rose-Ackerman 2006; Prud'homme 1995; Gurgur and Shah 2005; Treisman 2000b; Fan et al. 2009). This relationship does not apply in the case of fiscal decentralization (transfer of competencies from the central level to lower levels of management), which in turn reduces the magnitude of corruption (Fisman and Gatti 2002; Arikan 2004; Freille et al. 2008). 
In addition to a stable parliamentary democracy, the risk of corrupt practices in the public sector is reduced by a guarantee of political accountability (Adsera et al. 2003; Ackerman 2004) and freedom of the press (Besley et al. 2002; Freille et al. 2007; Kalenborn and Lessmann 2012). A free and independent press plays an important role in informing society, especially in a situation where the society is active and can apply pressure on the responsible behaviour of political institutions.

Unlike economists and political scientists, sociologists attribute the causes of corruption in particular to factors associated with the nature of man and the culture of the environment where he lives (Sičáková-Beblavá and Beblavý 2007). Traditions, the historical development of the country, can qualify as unwritten (informal) rules that affect the prevalence of corruption to a greater intensity than written (formal) rules and even have much more longevity (Pauliniová 2001; Sičáková and Zemanovičová 2000; Srebalová 2014). This overview of the factors of corruption in the public sector is in line with the statement that "corruption is the result - a response to the legal, economic, cultural and political institutions in the relevant country" (Svensson 2005, 22).

\section{Objectives and methodology}

The aim of the study is to identify the factors of corrupt acts in the public sector stemming from the economic, political, cultural and social environments. Through the medium of the Delphi method we verify the relevance of economic, political and cultural-social factors of corrupt acts theoretically defined on the basis of the results of the study of this issue. The following factors are the test subjects:

\section{FACTORS IN THE SPREAD OF CORRUPTION IN THE PUBLIC SECTOR}

\begin{tabular}{l|l|}
\hline $\begin{array}{l}\text { Freedom in decision-making } \\
\text { Arising from the complexity of laws, gaps or shortcomings } \\
\text { in the standards themselves or their complete absence } \\
\text { (independent interpretation of laws according to their } \\
\text { needs). }\end{array}$ & $\begin{array}{l}\text { Klitgaard (1998); Staroňová } \\
\text { and Sičáková-Beblavá (2009); } \\
\text { Pauliniová (2001); Zemanovičová } \\
\text { et al. (2001); Durajková et al. } \\
\text { (2004) }\end{array}$ \\
\hline $\begin{array}{l}\text { Monopolies and extensive regulation } \\
\text { Monopoly is the extreme market situation where the } \\
\text { market is dominated by one company and allows } \\
\text { production. It is associated with the prevalence of demand } \\
\text { over supply and leads to its creation and the difficulty of } \\
\text { complying with state regulation. }\end{array}$ & $\begin{array}{l}\text { Klitgaard (1998); Bažantová } \\
\text { (2007); Broadman and Recanatini } \\
\text { Treisman (1999); Lambsdorff and } \\
\text { Cornelius (2000) }\end{array}$ \\
\hline $\begin{array}{l}\text { Conflict of interests } \\
\text { Personal or other relations of the participating parties lead } \\
\text { to a threat to the objective execution of functions and } \\
\text { fulfilling tasks. }\end{array}$ & \begin{tabular}{l} 
Pauliniová (2001) \\
\hline $\begin{array}{l}\text { Public-sector institutions } \\
\text { In relation to the size of the public sector; the greater } \\
\text { number of employees, the more likely is inefficient } \\
\text { expansion of bureaucracy, reduction of quality and } \\
\text { incidences of petty corruption. }\end{array}$
\end{tabular} \\
\hline
\end{tabular}




\begin{tabular}{|c|c|}
\hline $\begin{array}{l}\text { Degree of competition } \\
\text { Low level of competition increases the possibility and } \\
\text { motivation for personal gain. }\end{array}$ & $\begin{array}{l}\text { Rose-Ackerman (2006); Ades and } \\
\text { Di Tella (1999); Emerson (2005) }\end{array}$ \\
\hline $\begin{array}{l}\text { Degree of democracy } \\
\text { A Transparency International report says that in a } \\
\text { democracy where the driving force is that of the political } \\
\text { parties, there is more room for corruption. }\end{array}$ & $\begin{array}{l}\text { Rock (1994); Treisman (1999); } \\
\text { Heidenheimer et al. (1989); Rose- } \\
\text { Ackerman (2006); Gerring and } \\
\text { Thacker (2004); Ledrman et al. } \\
\text { (2001); McLeod (2005); Robinson } \\
\text { and Hadiz (2004); Cause (2002) }\end{array}$ \\
\hline $\begin{array}{l}\text { Financing of political parties } \\
\text { The possibility of influence of interest groups in the } \\
\text { decision-making process, through the financing of political } \\
\text { parties. }\end{array}$ & $\begin{array}{l}\text { Sičáková and Zemanovičová } \\
(2000)\end{array}$ \\
\hline $\begin{array}{l}\text { Weak control mechanism (enforcement, penalties) } \\
\text { Results in a low risk of detection and bearing the } \\
\text { consequences in comparison with the possible profits. }\end{array}$ & Zemanovičová (2002) \\
\hline $\begin{array}{l}\text { Decentralization (fiscal, political) } \\
\text { "Bringing the government closer to people", the existence } \\
\text { of the possibility to control local government by strong } \\
\text { entities active in the area; more levels can create more } \\
\text { space for the emergence of corruption. }\end{array}$ & $\begin{array}{l}\text { Rose-Ackerman (2006); } \\
\text { Prud'homme (1995); Gurgur and } \\
\text { Shah (2005), Treisman (2000b); } \\
\text { Fan et al. (2009); Tanzi (1996); } \\
\text { Arikan (2004); Freille et al. (2008) }\end{array}$ \\
\hline $\begin{array}{l}\text { Degree of economic freedom } \\
\text { Degree of influence of government in relation to decision- } \\
\text { making on production or consumption of goods and } \\
\text { services beyond the scope of what is necessary for the } \\
\text { preservation of freedom itself. }\end{array}$ & $\begin{array}{l}\text { Chaufen (2012); Swaleheen and } \\
\text { Stansel (2007) }\end{array}$ \\
\hline $\begin{array}{l}\text { Transparency in the political system } \\
\text { Public decisions that are not carried out in open and } \\
\text { competitive conditions create a space for the emergence of } \\
\text { corrupt behaviour. }\end{array}$ & $\begin{array}{l}\text { Pauliniová (2001); Ďurajková et } \\
\text { al. (2004) }\end{array}$ \\
\hline $\begin{array}{l}\text { Credibility of the police services } \\
\text { To what extent is it possible to count on police services to } \\
\text { enforce compliance with the law and resolve complaints. }\end{array}$ & $\begin{array}{l}\text { Lambsdorff and Cornelius (2000); } \\
\text { Pepys (2007); Moyo (2007) }\end{array}$ \\
\hline $\begin{array}{l}\text { Favouritism in politicians' decision-making } \\
\text { If politicians favour their relations with individuals, } \\
\text { companies within political decisions. }\end{array}$ & Ďurajková et al. (2004) \\
\hline $\begin{array}{l}\text { Degree of dependence of the courts } \\
\text { If the courts are dependent on individuals, businesses and } \\
\text { so on, there is the possibility of a smaller number who are } \\
\text { convicted for corrupt practices. }\end{array}$ & $\begin{array}{l}\text { Rose-Ackerman (2006); Ades and } \\
\text { Di Tella (1996); Sung (2002); } \\
\text { Damania et al. (2004) }\end{array}$ \\
\hline $\begin{array}{l}\text { Lack of legal regulation of lobbying } \\
\text { If lobbying is not legally defined, it can turn into acts of } \\
\text { corruption. }\end{array}$ & Pauliniová (2001) \\
\hline $\begin{array}{l}\text { Media } \\
\text { The degree of objectivity of the media has an impact } \\
\text { on public opinion and is capable of either eliminating or } \\
\text { encouraging corruption. }\end{array}$ & $\begin{array}{l}\text { Besley et al. (2002); Freille et al. } \\
(2007) ; \text { Kalenborn and Lessmann } \\
(2012) ; \text { Durajková et al. (2004) }\end{array}$ \\
\hline $\begin{array}{l}\text { Poor quality of education system } \\
\text { The prerequisite for a high degree of development of a } \\
\text { country is a knowledgeable society, and in such countries, } \\
\text { there is usually a lower rate of corruption. }\end{array}$ & $\begin{array}{l}\text { Mauro (1998a); Hegeman and } \\
\text { Berumen (2011) }\end{array}$ \\
\hline $\begin{array}{l}\text { Extent of the tax burden } \\
\text { High tax burdens can cause widespread informal economy } \\
\text { and corrupt practices. }\end{array}$ & $\begin{array}{l}\text { Ghura (1998); Tanzi and Davoodi } \\
\text { (2000); Attila (2008) }\end{array}$ \\
\hline
\end{tabular}




\begin{tabular}{|c|c|}
\hline $\begin{array}{l}\text { Customs and traditions } \\
\text { Determine the nature of man and originate from an earlier } \\
\text { age - corrupt traditions (note, etc.). }\end{array}$ & $\begin{array}{l}\text { Sičáková and Zemanovičová } \\
(2000)\end{array}$ \\
\hline $\begin{array}{l}\text { Scale of values } \\
\text { If the first level is occupied by personal gain or material } \\
\text { goods, there is the potential for corruption in order to } \\
\text { achieve them. }\end{array}$ & Dion (2013) \\
\hline Morals & Moriconi and Carvalho (2016) \\
\hline Tolerance of corruption & $\begin{array}{l}\text { Sičáková and Zemanovičová } \\
(2000)\end{array}$ \\
\hline $\begin{array}{l}\text { Ethical infrastructure } \\
\text { If it is not created, there are no tools to eliminate any } \\
\text { unwanted proceedings (acts of corruption). }\end{array}$ & Svensson (2005) \\
\hline $\begin{array}{l}\text { Political stability of the country } \\
\text { Citizens in a politically unstable country face shortages, } \\
\text { and in light of the efforts to ensure common needs, this } \\
\text { leads to the creation of room for corruption. }\end{array}$ & Mauro (1998b) \\
\hline $\begin{array}{l}\text { Corrupt models } \\
\text { Corrupt behaviour of individuals, firms and the elite can be } \\
\text { a model for society. }\end{array}$ & Cartier-Bresson (1997) \\
\hline $\begin{array}{l}\text { Inactive civil society } \\
\text { Insufficient public opinion puts pressure on politicians (by } \\
\text { means citizens participation in public decision and control } \\
\text { processes). }\end{array}$ & $\begin{array}{l}\text { Sičáková and Zemanovičová } \\
(2000)\end{array}$ \\
\hline $\begin{array}{l}\text { Degree of competition in the system of providing } \\
\text { public services } \\
\text { If the services are not transparent, there is greater room } \\
\text { for possible corruption. }\end{array}$ & $\begin{array}{l}\text { Ochrana and Maaytová (2012); } \\
\text { Tanzi (1998) }\end{array}$ \\
\hline Code of Ethics in public sector organisations & Meričková (2005) \\
\hline $\begin{array}{l}\text { Income levels of public servants } \\
\text { There is the presumption that if public-sector wages are } \\
\text { low, the employees will try to improve their financial } \\
\text { situation and will be more likely to accept bribes. }\end{array}$ & $\begin{array}{l}\text { Rijckeghem and Weder (1997); } \\
\text { Tanzi (1998); Sičáková-Beblavá } \\
\text { and Beblavý (2007) + group of } \\
\text { experts }\end{array}$ \\
\hline
\end{tabular}

Source: author's own

The Delphi method is a method which involves a group of experts in the research methods. Benčo (1998) classified the Delphi method according to the process of formulating developing conditions for a group of subjective methods and in terms of the direction of forecasting to explorative, as well as that of a standard method. "The method is effected by a deliberately elected system of issues in the study area which are put to the selected group of experts in the form of a questionnaire or personal interview conducted by the questionnaire organizer with individual experts to determine their individual opinion; however, the individual survey participants (expert) never come into contact with the other experts" (Benčo and Pastier 1996, 42). This comprehensive definition using the Delphi method captures its essence and also the conditions under which they can be realized. The basic characteristics of this method are, according to Listone and Turoff $(2002,206)$ : the anonymity of experts, feedback control and the statistical determination of a con- 
sensus of experts. The method comprises several steps. Klučka $(2009,112)$ defines five steps:

1. "Defining the problem

2. by providing the first initiative in the framework of the first round,

3. summary and conclusions from the first round,

4. repeating steps 2 and 3 until conclusions are obtained,

5. completion."

The essence of using the Delphi method is the logical sequence of steps. In preparation for drawing up the questionnaire we pay attention to analyzing domestic and foreign literature in order to obtain objective information on the factors underlying corrupt behaviour in society (i.e. we do not leave the selection of factors underlying corrupt behaviour to subjective perception, but each factor in the questionnaire is supported by the theoretical basis). Subsequently, we compile a questionnaire which is then presented to the selected experts. The number of experts for the implementation of this method varies in the literature. There are opinions that a larger group of experts should be addressed; there are, however, also opinions that it should be smaller or even in the middle between these extremes. Listone and Turoff (2002) reported the sufficient number of experts as ranging from 15 to 35 . A similar number (15-25 experts) is also forwarded by Papula (1995). Grznár (2011) prefers a smaller group and inclines to $10+/$ - 2 experts, together with Němec (2002), who, given the need for statistical evaluation, states a minimum of four experts. The middle ground, i.e. 10-20 experts, is forwarded by not only Benčo and Pastier (1996), but also by Magdolenová (2009). According to Reichel (2009), the number of experts may depend also on the extensiveness of the research, which is typically $50-100$, and for large-scale international research the number may be several hundred experts. For local research, a smaller number of experts will in all likelihood be approached than at the international level. After the first-round takes, evaluation takes place in order "to obtain a picture of the total variance in the answers to the questions and to get an idea about the prevailing opinion" (Magdolenová 2009, 3). On the basis of the fulfilment of the conditions of feedback it is necessary to send an evaluation of the first round back to the experts to offer them the opportunity to change their opinion (this option does not have to be used). While the first round is carried out in order to detect the variance of responses, the second round is focused on their prevalence and convergence. Further rounds are conducted in such a number in order to achieve a sufficient degree of agreement between the experts. Magdolenová (2009) points out that the achievement of group consensus of experts forgets that the majority view is not always best. In our case, the examined factors underlying corrupt behaviour, in terms of statistics, have the nature of ordinal (paired) characters.

The evaluation of the results using the Delphi method involves the expression of the values of standardized discrete ordinal variance, which expresses the variabil- 
ity of respondents' answers and can take values from the interval $<0,1>$. If its value is closer to 0 , there is the lower the variability of responses, respondents agreed to a greater extent when choosing the relevancy of factors underlying corrupt behaviour. Values approaching 1 indicate a more dispersed responses, i.e. that the choice of the degree of relevancy to the individual factors underlying corrupt behaviour was diverse. Standardized discrete ordinal variance is determined on the basis of frequency tables by means of statistical programmes using the following equation:

$\operatorname{ord}($ var $)=\frac{4}{K-1} \sum_{i=1}^{K} F_{i}\left(1-F_{i}\right)$, where

$\mathrm{K}$ - number of categories of ordinal variables

$\mathrm{F}_{\mathrm{i}}$ - relative frequency of the $\mathrm{i}^{\text {th }}$ category

After determining the value of a standardized discrete ordinal variance, we can proceed to calculate the median, according to which we express the overall relevance of the factors underlying corrupt behaviour. The median is more appropriate than the arithmetic mean, because of its lower sensitivity to extreme values. It determines the median centre of the distribution and can be calculated by the following equation:

$$
\widetilde{x}=a+h * \frac{0,5 *\left(n_{i}+1\right)-\sum_{i=1}^{r-1} n_{i}}{n_{i}} \text {, where }
$$

a - lower limit of the median interval

$h \quad$ - width of the median interval

$\sum_{i=1}^{r-1} n_{i}$ - sum of the frequencies for the median interval

$n_{i} \quad$ - frequency of the median interval

The median expresses the middle of the respondents' answers (i.e. that half of the respondents provided values less than the median and again that half of the values were greater than the median). Furthermore, the median is also used to express the overall relevance of the factors that were calculated as follows:

$\frac{\text { Median }}{\text { Total number of possibilites }} * 100$, where

Median - median of respondents' answers

Total number of options - the number of options on a scale in assessing the relevance of the factors underlying corrupt behaviour $(0$ - no relevance ... 5 the highest relevance factor underlying corrupt behaviour) 
After the value of the standardized discrete ordinal variance is stated, we can calculate the median and figure out the relevance of factors underlying corrupt behaviour. This order is determined on the basis of the Friedman test, which, according to Rimarčík (2007), is used "to verify the relationship between nominal and ordinal variables. It represents a non-parametric alternative to the two-factor analysis of variance and is similar to the Kruskal-Wallis test for dependent samples." Markechová et al. $(2011,321)$ report that the "Friedman test is a generalization of the Wilcoxon one-sample test, and the analogy of double classification analysis of variance with one observation in each subclass." Within the Friedman test, the null hypothesis $\mathrm{H}_{0}$ is tested, which talks about the identity of the distribution functions of the variables $\left(X_{\mathrm{i} 1}, X_{\mathrm{i} 2}, \ldots, X_{\mathrm{ik}}\right)$. In our case, $X_{\mathrm{ij}}(i=1, \ldots, n ; j=, \ldots, k)$ are independent factors underlying corrupt behaviour, where $n$ is the number of lines and $k$ is the number of columns, whereby $n$ denotes the sample size, whereas $k$ the number tested and is, at the same time, a random variable with continuous distribution functions Fij. Markechová et al. $(2011,321)$ reports that the Friedman test is often referred to as the so-called random block model, which "is the fact that the observations on each block is separately arranged and determines the order of $T_{\mathrm{ij}}$ values Xij within the $i$-th block." The collective of authors furthermore present the following statistics as a test criterion:

$$
Q=\frac{12}{n k(k+1)} * \sum_{j=1}^{k}\left(\sum_{i=1}^{n} T_{i j}\right)^{2}-3 n(k+1), \text { which }
$$

"has the validity of the hypothesis $\mathrm{H}_{0}$ asymptotically $\chi^{2}$ - distribution with $\mathrm{k}-1$ degrees of freedom. Testing the hypothesis $\mathrm{H}_{0}$ is rejected at the significance plane $\alpha$ if the value of the test criterion $Q \geq \chi_{\alpha}^{2}(k-1)$, where $\chi_{\alpha}^{2}(k-1)$ are critical values $\chi^{2}$ - distribution with k-1 degrees of freedom." Our set includes 29 factors underlying corrupt behaviour, i.e. the selection is of a wide range ( $n>20)$, and therefore we can use the previous equation. Otherwise, "for small values of $\mathrm{n}$ and $\mathrm{k}(n \leq 20, k \leq 12)$ the value of the test criterion $Q$ is compared with the critical value $Q_{\alpha}$ of the Friedman test. The test hypothesis $\mathrm{H}_{0}$ is rejected at significance plane $\alpha$, if $Q \geq Q_{\alpha}$ " (Markechová et al. 2011, 322).

\section{Results and discussion}

In identifying the factors of corrupt acts in the public sector stemming from the economic, political, cultural and social environments in the Slovak Republic the country context should by considered. We shortly describe it. The Slovak Republic 
is situated at the centre of Europe and has an area of $49,034 \mathrm{~km}^{2}$. The total number of inhabitants of the Slovak Republic is about 5.5 million. Slovakia has been established on 1 January 1993, as a result of the split of former Czechoslovakia, as an independent sovereign, democratic unitary state, based on the Rule of Law (Constitution of the Slovak Republic). The Slovak Constitution was ratified on 1 September 1992, fully effective on 1 January 1993; it was changed in September 1998 to allow direct election of the president; amended in February 2001 to allow Slovakia to apply for NATO and EU membership. The head of the executive branch is the President, elected by direct popular vote for a five-year term. The head of government is the Prime Minister. The Cabinet is appointed by the President on the recommendation of the Prime Minister. The legislative branch is represented by the unicameral National Council of the Slovak Republic; members are elected on the basis of proportional representation to serve four-year terms. The judicial branch is represented by the Supreme Court (judges are elected by the National Council) and Constitutional Court (judges appointed by president from group of nominees approved by the National Council).

The public-administration concept of the country is unclear and not defined by any existing official document. A very typical feature of it is over-legalization, i.e. the will to solve existing problems by legislative changes via the legal system. In the conditions of using the Delphi method we discovered the opinions of the members of the expert group (Table 1) concerning the relevance of the factors underlying corrupt behaviour.

\section{Table 1}

Expert group

\begin{tabular}{|l|c|c|c|c|c|c|}
\hline \multirow{2}{*}{ Scope } & \multicolumn{2}{|c|}{ Private } & \multicolumn{2}{c|}{$\begin{array}{c}\text { Scientific } \\
\text { research }\end{array}$} & \multicolumn{2}{c|}{ Total } \\
\cline { 2 - 7 } & 1. round & 2. round & 1. round & 2. round & 1. round & 2. round \\
\hline Number of respondents & 7 & 6 & 8 & 6 & 15 & 12 \\
\hline Percentage distribution & $46.67 \%$ & $50 \%$ & $53.33 \%$ & $50 \%$ & $100 \%$ & $100 \%$ \\
\hline $\begin{array}{l}\text { Average number of } \\
\text { years of experience }\end{array}$ & 6.3 & 5.6 & 11.3 & 10 & 8.8 & 7.8 \\
\hline
\end{tabular}

Source: author's own

The researched factors underlying corrupt behaviour originate from political, economic or cultural-social environments, and they are of organizational, economic, micro-economic and macro-economic natures. The systematic orderly sorting of them into groups is not possible because they do not operate in isolation but are mutually linked. In terms of statistics, however, they are viewed as ordinal (sequential) characters. For their evaluation, therefore, we use the median, which, due to its 
lower sensitivity to extreme values is more appropriate than the arithmetic mean. Using the median, we found the middle of the respondents' answers, i.e. that half of the respondents provided values below the median and again that half of the values were greater than the median. The aim of using the Delphi method is to achieve a "group opinion". To evaluate we therefore discovered the degree of variability of ordinal characters. Based on the frequency tables as output from the statistical programme SPSS, we then calculated the standardized discrete ordinal variance:

$$
\operatorname{ord}(\text { var })=\frac{4}{K-1} \sum_{i=1}^{K} F_{i}\left(1-F_{i}\right) \text {, where }
$$

$\mathrm{K}$ - number of categories of ordinal variables,

$\mathrm{F}_{\mathrm{i}}$ - relative frequency of the i-th category.

The standardized discrete ordinal variance takes values from $<0-1>$. If its value of the standardized discrete ordinal variance is closer to 0 , there is the lower the variability of responses, respondents agreed to a greater extent when choosing the relevancy of factors underlying corrupt behaviour. Values approaching 1 indicate greater diffuseness, i.e. that the selection of the degree of relevancy for individual factors underlying corrupt behaviour was more diverse. In the following table, we present the achieved median values, variance as the overall relevance of the individual factors underlying corrupt behaviour in the first and second rounds of the Delphi method.

In the first round, most of the achieved variances oscillated around a value of 0.5 .15 factors underlying corrupt behaviour in the public sector reached a variance value above 0.5 , which corresponds to $53.57 \%$ of the total group of factors underlying corrupt behaviour. Medium-sized variance in the answers in this research phase was expected. This means that some answers were consistent while others were in conflict; they were neither homogeneous nor heterogeneous, suggesting the reliability of the research. In the second round, the variance changed for many of the factors underlying corrupt behaviour and a value above 0.5 was achieved by only 8 factors underlying corrupt behaviour in the public sector. This means that the consistency of the response was more homogeneous than in the first round and that the expert group reached a certain degree of consensus. Values of a low rate of variability are marked by italics in the table, factors for which the expert group agreed on the relevant impact on corrupt behaviour in the public sector. Conversely, high values of the rate of variability are marked in bold, i.e. where the expert group clearly disagreed on the evaluation of the relevance of the factors underlying corrupt behaviour. All the observed factors underlying corrupt behaviour can be classified into seven groups divided by relevance. The first group with $83.33 \%$ overall relevance comprises the factors underlying corrupt behaviour operating at an informal level (morals, scale of values) and the factors underlying corrupt behav- 


\section{Table 2}

Relevance of underlying factors in corrupt behaviour (expert group)

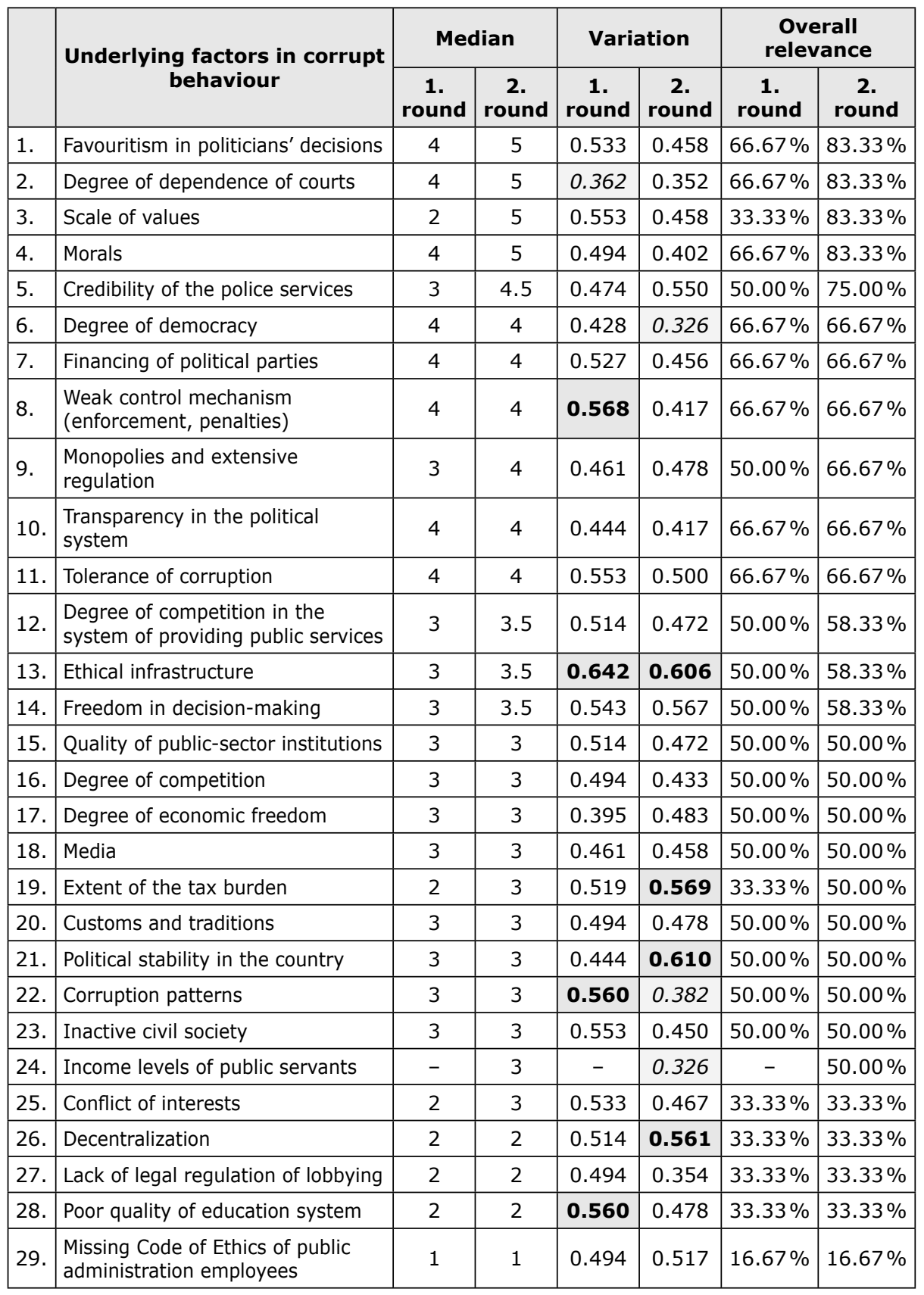

Source: processing based on author's own primary research 
iour in the public sector associated with political and judicial environments. This is followed by the second group, where $75 \%$ of the overall relevance comprises the factors underlying corrupt behaviour which we named the credibility of the police service. The intuitional link between police and the prosecutor nexus has an important role in this case.

The third group, according to relevance, includes the factors underlying corrupt behaviour characteristic of regulatory and organizational interventions (with the exception of tolerance to corruption, i.e. a factor underlying corrupt behaviour that operates at an informal level). The fourth group, according to relevance, combines the factors underlying corrupt behaviour in the public sector which have an economic or organizational background, and, in the case of the ethical infrastructure, are also informal. The fifth group of factors underlying corrupt behaviour is the most numerous and included here are the factors underlying corrupt behaviour that have an overall relevance of $50.00 \%$. The expert group considered them to be of intermediate relevance, and we are unable to identify a common feature between them. The sixth group consists of four factors underlying corrupt behaviour in the public sector, stemming mostly from the political environment, except for the factor concerning the quality of the education system. The last group, with the lowest overall relevance of only $16.67 \%$, includes the missing Code of Ethics of publicadministration employees. Besides this factor underlying corrupt behaviour we also included a related factor, namely ethical infrastructure with an overall relevance of $58.33 \%$, which is $41.66 \%$ more than for the Code of Ethics. Thus, we can conclude that in this case, the expert group considered precisely the non-developed ethical infrastructure in the country to be a more serious problem than the lack of a Code of Ethics of employees in public-administration organizations.

\section{Conclusion}

As mentioned in the introduction part, the conceptualization of corruption varies considerably, and we know that there is a closed set of factors that influence corruption in the public sector. An example might be a study of Del Monte and Papagni (2007), who state that in Italy the patronage system is the most important factor. The level of corruption in the public sector differs between Italian regions, and the decrease in the level of corruption after 1993 could be explained by political and cultural variables and not by economic variables. The research has shown that interventionism does not seem an important cause of corruption in the public sector. This is confirmed by studies from Treisman (2000a). The study from Moriconi and Carvalho (2016) states that corruption should be assessed taking into account social class.

Members of our expert group considered those factors underlying corrupt behaviour in the public sector arising out of the political environment (the influence 
of political institutions is verified by Jain 2001), as well as factors underlying corrupt behaviour arising from the cultural-social environment as more relevant (the same results were achieved by Dion 2013). The most overall relevance is held by factors underlying corrupt behaviour in the public sector operating at an informal level (morals, scale of values - corruption patterns; our results are confirmed by Moriconi and Carvalho 2016, who added in their study that the level of tolerance of corruption varies according to social classes) and the factors underlying corrupt behaviour in the public sector associated with political environment (degree of democracy) and judicial environment (degree of dependence of courts). Similar conclusions are known from studies of corruption environment, for example in China (Wang 2013), Latin America (Ríos-Figueroa 2012), Russia (Schultz et al. 2014), Portugal (Stockemer and Calca 2013) and many other countries.

Factors underlying corrupt behaviour in the public sector arising out of the economic environment were assigned mostly to the third level as determined by the scale of relevance, which means that members of the group considered political and cultural-social factors to be more relevant than economic ones (the only important economic factor were the income levels of public servants). On the contrary, Moriconi and Carvalho (2016) argue that the importance of economic factors is highly correlated only in socially vulnerable layers of the population. Based on the obtained values of total relevancy of factors underlying corrupt behaviour in the public sector we can say that in first place are the factors underlying corrupt behaviour that operate at an informal level and emanate from the jurisdiction and police environments (which is confirmed in a study by Montinola and Jackman 2002). Marques (2010) complements our conclusions and argues that corrupt behaviour in the public sector is also influenced by the high levels of impunity, when citizens see how members of different elites are not punished after being denounced for corruption.

Our expert evaluation of the factors underlying corrupt behaviour in the public sector enabled us to not only detect the overall relevance of the factors, but also identify areas where corruption is most widespread according to experts. We can state that the most problematic areas include the judiciary and the police. Our conclusions may be adding to the study by Misangyi et al. (2008), who suggest that society should rely on market liberalization and legal accountability, on a more complex dynamic of individual, organizational and institutional phenomena that work together to create and maintain corruption or to create opportunities for mitigating corruption in the public sector.

\section{Acknowledgement}

This paper was published as a part of the research projects: GACR 16-13119S - Performance management in public administration - theory vs. practices in the Czech 
Republic and other CEE countries and VEGA 1/0405/15 Programme budgeting as a New public management tool.

\section{References}

Ackerman, J. 2004. “Co-Governance for Accountability: Beyond 'Exit' and 'Voice”.' World Development 32(3), 447-463.

Ades, A. and R. Di Tella. 1996. "The Causes and Consequences of Corruption: A Review of Recent Empirical Contributions.” In B. Harris-White and G. White. Liberalisation and the New Corruption. Brighton: Institute of Development Studies. Available at http://www.idpp.ac.uk/idspublication/liberalizationand-the-new-corruption (last accessed 27 September 2013).

Ades, A. and R. Di Tella. 1999. "Rents, Competitions, and Corruption." The American Economic Review 89(4). Available at http://conferencepp.wcfia.harvard. edu/sites/projectpp.iq.harvard.edu/files/gov2126/files/aerentscorruption.pdf (last accessed 27 September 2012).

Adsera, A., C. H. Boix and M. Payne. 2003. "Are You Being Served? Political Accountability and Quality of Government." The Journal of Law, Economics, \& Organization 19(2), 445-490.

Apgar, W. C. and H. J. Brown. 1987. Microeconomics and Public Policy. London: Scott, Foresman and Company.

Arikan, G. G. 2004. “Fiscal Decentralization: A Remedy for Corruption?” International Tax and Public Finance 11(2), 175-195.

Attila, G. 2008. "Corruption, Taxation and Economic Growth: Theory and Evidence." CERDI-UMR CNRPP. Available at http://www.brunochiarini.it/conference/Attila.pdf (last accessed 16.12.2016 DATE).

Bailey, E. 1987. Public Regulation. London: The MIT Press.

Bardhan, P. 1997. “Corruption and Development: A Review of Issues." Journal of Economic Literature 35(3), 1320-1346.

Bažantová, I. et al. 2007. Lobbing a korupcie při tvorbě veřejné politiky. Praha: Prospektrum.

Beblavý, M. 2007. “Ekonomický pohlad na škodlivost' korupcie a jej možné riešenia.” Ekonomický časopis 55(7), 697-711.

Benčo, J. 1998. Základy metodológie vedeckého výskumu. Banská Bystrica: Ekonomická fakulta UMB Banská Bystrica.

Benčo, J. and J. Pastier. 1996. Metódy rozvoja kreativity v manažérskej práci. Bratislava: Nadácia učňovského školstva. 
Besley, T., R. Burgess and A. Prat. 2002. Mass Media and Political Accountability. The Right to Tell: The Role of Mass Media in Economic Development. Washington: World Bank Publications.

Bower, P. F. 1974. Private Choice and Public Welfare. Hinsdale: The Dryden Press.

Broadman, H. G. and F. Recanatini. 1999. Seeds of Corruption: Do Market Institutions Matter? Washington: World Bank Policy Research. Available at http:// ideapp.repec.org/p/wbk/wbrwps/2368.html (last accessed 30 October 2012).

Buchanan, J. M. 1996. Hranice slobody: Medzi anarchiou a Leviatanom. Bratislava: Archa.

Cartier-Bresson, J. 1997. "Corruption Network, Transaction Security and Illegal Social Exchange.” Political Studies Review 45(3), 463-476.

Cause, W. 2002. Politics in Southeast Asia: Democracy or Less. New York: Routledge.

Chaufen, A. 2012. "Economic Freedom and Corruption." Conservative Letters, M. R. Stefanik Conservative Institute. Available at http://www.institute.sk/article.php?4490 (last accessed 14 November 2014).

Damania, R., P. G. Fredriksson and M. Mani. 2004. "The Persistence of Corruption and Regulatory Compliance Failures: Theory and Evidence." IMF Working Paper WP/03/172. Available at https://www.imf.org/external/pubs/ft/ wp/2003/wp03172.pdf (last accessed 9 December 2013).

Del Monte, A. and E. Papagni. 2007. "The Determinants of Corruption in Italy: Regional Panel Data Analysis." European Journal of Political Economy 23(2), 379-396.

Dion, M. 2013. “Uncertainties and Presumptions about Corruption." Social Responsibility Journal 9(3), 412-426.

Djankov, P. P., R. La Porta, F. Lopez-De-Silanes and A. Shleifer. 2002, “The Regulation of Entry." Quarterly Journal of Economics 117(1), 1-37.

Ďurajková, D., D. Zemanovičová and M. Zuberská. 2004. Celospoločenský problem: Korupcia II. Bratislava: Adis.

Elliot, K. A. 1997. "Economic Analysis of Corruption." In K. A. Elliot et al. (eds). Corruption and the Global Economy. Washington: Institute for International Economics, 175-233.

Emerson, P. M. 2005. "Corruption, Competition and Democracy." Journal of Development Economics 81(1), 193-212. Available from:http://people.oregonstate. edu/ emersonp/ccd/ccd.pdf (last accessed 30 October 2012).

Fan, C. P. P., C. H. Lin and D. Treisman. 2009. "Political Decentralization and Corruption: Evidence from around the World." Journal of Public Economics 93(1), 14-34. 
Fisman, R. and R. Gatti. 2002. "Decentralization and Corruption: Evidence across Countries." Journal of Public Economics 83(1), 325-345.

Freille, P. P., M. Haque and R. Kneller. 2007. "A Contribution to the Empirics of Press Freedom and Corruption." European Journal of Political Economy 23(1), 838-862. Available at http://personalpagepp.manchester.ac.uk/staff/emranul.haque/ejpe_\%20press\%20freed\%20and\%20corruption_dec2007.pdf (last accessed 30 October 2012).

Freille, P. P., M. Haque and R. Kneller. 2008. Federalism, Decentralisation and Corruption. Centre for Economic Policy Research. Available at http://www.cepr. org/meets/wkcn/6/6675/papers/FreilleFinal.pdf (last accessed 30 October 2012).

Gerring, J. and P. P. Thacker. 2004. "Political Institutions and Governance: Pluralism versus Centralism.” British Journal of Political Science 34(2), 295-303.

Ghura, D. 1998. Tax Revenue in Sub-Saharan Africa: Effects of Economic Policies and Corruption. Social Science Research Network. Available at http://paperpp. ssrn.com/sol3/paperpp.cfm?abstract_id=882694 (last accessed 3 January 2013).

Graeff, P. and G. Mehlkop. 2003. “The Impact of Economic Freedom on Corruption: Different Patterns for Rich and Poor Countries." European Journal of Political Economy 19(3), 605-620.

Grznár, F. 2011. Komunikácia pomocou metód skupinového riešenia problému. Zbierka esejí: Manažment projektov softvérových a informačných systémov. Available at http://www2.fiit.stuba.sk/ bielik/courses/msi-slov/kniha/ (last accessed 14 October 2012).

Gurgur, T. and A. Shah. 2005. "Localization and Corruption: Panacea or Pandora's Box?” World Bank Policy Research Working Paper. Available at http://info. worldbank.org/etools/docs/library/206958/Localizationandcorruption.pdf (last accessed 1 November 2012).

Hayek, F. A. 1994. Právo, zákonodárství a svoboda: Nový výklad liberálních principů spravedlnosti a politické ekonomie. Praha: Akademie věd ČR.

Hegemann, P., P. P. A. Berumen. 2011. "A Neoschumpeterian Review of the Impact of Corruption on Competitiveness and Foreign Direct Investment." Papeles de Europa 22(1), 39-60.

Heidenheimer, A. J., M. Johnson and V. T. Levine. 1989. Political Corruption: A Handbook. New Brunswick, N. J.: Transaction Books.

Jain, A. K. 2001. “Corruption: A Review.” Journal of Economic Survey 15(1), 71-121. 
Kalenborn, C. H. and C. H. Lessmann. 2012. The Impact of Democracy and Press Freedom on Corruption: Conditionality Matters. Social Science Research Network. Available at http://paperpp.ssrn.com/sol3/paperpp.cfm?abstract_ id=2144137 (last accessed 5 January 2013).

Klitgaard, R. E. 1998. Controling Corruption. California: University of California Press.

Klučka, J. 2009. Plánovanie a prognostika v aplikáciách. Žilina: Žilinská univerzita v Žiline.

Lambsdorff, J., G. and P. Cornelius. 2000. "Corruption, Foreign Investment and Growth." In K. Schwab et al. (eds). The Africa Competitiveness Report 2000/2001. World Economic Forum and the Institute for International Development. Available at http://www.weforum.org/reports (last accessed 1 January 2013).

Ledrman, D., N. Loayaza and R. R. Soares. 2001. "Accountability and Corruption: Political Institutions Matter." World Bank Policy Research Working Paper. Available at http://coursepp.wcupa.edu/rbove/eco343/040compecon/general\%20compar/040300institut.pdf (last accessed 5 January 2013).

Listone, H. A. and M. Turoff. 2002. The Delphi Method: Techniques and Applications. Michigan: Addison-Wesley Pub. Co.

McCord, G. P. P. 1999. “Contemporary Contractarian Moral Theory." In H. LaFollette (ed.). The Blackwell Guide to Ethical Theory. Chichester: Blackwell, 247-267. Available at http://philosophy.unc.edu/files/2014/07/Contractarianism.pdf (last accessed 16.12.2016 DATE).

McLeod, R.H. 2005. "The Struggle to Regain Effective Government under Democracy in Indonesia." Bulletin of Indonesian Economic Studies 41(3), 367-386. Available at http://www.tandfonline.com/doi/abs/10.1080/00074910500117289 (last accessed 5 January 2013).

Magdolenova, J. 2009. Empirické metódy rozhodovania v manažmente. Žilinská univerzita v Žiline. Available at http://dspace.upce.cz/bitstream/10195/32318/1/ CL662.pdf (last accessed 15 January 2013).

Markechová, D. et al. 2011. Štatistické metódy a ich aplikácie. Nitra: Univerzita Konštantína Filozofa v Nitre.

Marques, D. 2010. Corrupção Fora de Prazo: Prescrição de Crimes Na Justiça Portuguesa [Out of Date Corruption: Limiting Crimes in the Portuguese Justice System]. Lisbon: Transparência e Integridade.

Mauro, P. 1998a. "Corruption: Causes, Consequences and Agenda for Further Research.” Finance \& Development 35(1), 11-14. 
Mauro, P. 1998b. "Corruption and the Composition of Government Expenditure." Journal of Public Economics 69(1), 263-279.

Meričková, B. 2005. “Etika vo verejnej správe a verejné obstarávanie: Korupcia vo verejnom obstarávaní a možné opatrenia v záujme jej prevencie.” Acta oeconomica 18, 214-221.

Mill, J. S. 2001 [1863]. Utilitiarism. Ontario: Batoche Books Limited. Available at http://socserv.mcmaster.ca/econ/ugcm/3ll3/mill/utilitarianism.pdf (last accessed 16.12.2016 DATE).

Misangyi, V. F., G. R. Weaver and H. Elms. 2008. "Ending Corruption: The Interplay among Institutional Logics, Resources, and Institutional Entrepreneurs." Academy of Management Review 33(3), 750-770.

Montinola, G. R. and R. W. Jackman. 2002. "Sources of Corruption: A Cross-Country Study." British Journal of Political Science 32(1), 147-170.

Moriconi, M. and T. Carvalho. 2016. "Social Classes and Tolerance to Corruption in Portugal: What is the Relationship?" Portuguese Journal of Social Science 15(2), 299-318.

Moyo, G. 2007. "Corrupt Judges and Land Rights in Zimbabwe." In Global Corruption Report 2007: Corruption in Judicial System. Transparency International. Available at http://www.transparency.org/whatwedo/pub/global_corruption_report_2007_corruption_and_judicial_system (last accessed 12 December 2013).

Nemec, J. 1998. "The Role of the State in Transitional Economies: Selected Microeconomic." Ekonomický ćasopis 46(5), 655-670.

Němec, V. 2002. Projektový management. Praha: Grada Publishing.

Nye, J. P. P. 1967. "Corruption and Political Development: A Cost-Benefit Analysis.” American Political Science Review 61(2), 417-427.

Ochrana, F. and A. Maaytová. 2012. "Východiska pro vytváření transparentního a nekorupčního systému zadávání veřejných zakázek." Ekonomický časopis 60(7), 732-745.

Panizza, U. 2001. "Electoral Rules, Political Systems, and Institutional Quality." Economics and Politics 13(3), 311-342.

Papula, J. 1995. Strategický manažment. Bratislava: Ekonóm.

Pauliniová, Z. 2001. Etika a korupcia v podnikaní. Bratislava: Róbert Vico vydavatel'stvo. 
Pepys, M. N. 2007. “Corruption within the Judiciary: Causes and Remedies.” In Global Corruption Report 2007: Corruption in Judicial System. Transparency International. Available at http://www.transparency.org/whatwedo/pub/ global_corruption_report_2007_corruption_and_judicial_systems (last accessed 12 December 2013).

Prud'homme, R. 1995. “The Dangers of Decentralization.” In World Bank Research Observer 10(2), 201-220.

Reichel, J. 2009. Kapitoly metodologie sociálních výzkumů. Praha: Grada Publishing.

Rijckeghem, C. and B. Weder. 1997. "Corruption and the Rate of Temptation: Do Low Wages in the Civil Service Cause Corruption?” International Monetary Fund Working Paper. Available at http://www.imf.org/external/pubs/ft/wp/ wp9773.pdf (last accessed 5 January 2013).

Rimarčík, M. 2007. Štatistika pre prax. Košice: Marián Rimarčík.

Ríos-Figueroa, J. 2012. “Justice System Institutions and Corruption Control: Evidence from Latin America." Justice System Journal 33(2), 195-214.

Robinson, R. and V. Hadiz. 2004. Reorganising Power in Indonesia. New York: Routledge Curzon.

Rock, M. T. 1994. Transitional Democracies and the Shift to Export-Led Industrialization: Lessons from Thailand. Studies in Comparative International Development. Available at http://www.researchgate.net/publication/225660088_ Transitional_democracies_and_the_shift_to_exportled_industrialization_ Lessons_from_Thailand (last accessed 10 December 2012).

Rose-Ackerman, P. P. 2006. International Handbook on the Economics of Corruption. Cheltenham: Edward Elgar.

Schultz, A., V. Kozlov and A. Libman. 2014. "Judicial Alignment and Criminal Justice: Evidence from Russian Courts” Post-Soviet Affairs 30(2-3), 137-170.

Sičaková, E. and D. Zemanovičová. 2000. Konflikt záujmov, etika a etický kódex vo verejnej správe. Bratislava: Róbert Vico - vydavatel'stvo.

Sičáková-Beblavá, E. and M. Beblavý. 2007. "Prístupy k definovaniu korupcie." Sociológia 39(4), 316-336.

Srebalová, M. 2014. "Reformy verejnej správy a štátna správa." In Organizace státní správy: Vývojové tendence. Praha: Leges, 90-97.

Stampford, C. H. et al. 2006. Measuring Corruption. Hampshire: Ashgate Publishing Limited.

Staroňová, K. and L. Malíková. 2007. "Pohlad politológie na fenomén korupcie." Sociológia 39(4), 287-315. 
Staroňová, K. and E. Sičaková-Beblavá. 2009. Corruption and Anti-Corruption Measures in Central and Eastern Europe. Bratislava: NISPAcee Press.

Stockemer, D. and P. Calca. 2013. "Corruption and Turnout in Portugal: A Municipal Level Study." Crime, Law and Social Change 60(5), 535-548.

Sung, H. E. 2002. A Convergence Approach to the Analysis of Political Corruption: A Cross-National Study. Crime, law and Social Change. Available at https:// www.ncjrpp.gov/App/publications/abstract.aspx?ID=234871 (last accessed 1 October 2013).

Svensson, J. 2005. "Eight Questions about Corruption." The Journal of Economic Perspectives 19(3), 19-42.

Swaleheen, M. and D. Stansel. 2007. "Economic Freedom, Corruption and Growth." Cato Journal 27(3), 343-358.

Štička, Michal et al. 2005. Korupce a protikorupční politika ve veřejné správě. Praha: Transparency International. Definice korupce, Available at http://www.transparency.cz/index.php?lan=cz\&id=2680 (last accessed 13 March 2010).

Tanzi, V. 1996. "Fiscal Federalism and Decentralization: A Review of Some Efficiency and Macroeconomic Aspects." In M. Bruno and B. Pleskovic (eds). Annual World Bank Conference on Development Economics 1996. Washington D.C.: World Bank, 295-315.

Tanzi, V. 1998. "Corruption Around the World: Causes, Consequences, Scope and Cures." International Monetary Fund. Available at http://www.imf.org/external/pubs/ft/wp/wp9863.pdf (last accessed 27 December 2012).

Tanzi, V. and H. R. Davoodi. 2000. "Corruption, Growth, and Public Finances." International Monetary Fund Working Paper WP/00/182. Available at http:// www.imf.org/external/pubs/ft/wp/2000/wp00182.pdf (last accessed 1 May 2012).

Treisman, D. 1999. "Decentralisation and Ccorruption: Why are General States Perceived to be More Corrupt." Journal of Public Economics 76(2), 399-457.

Treisman, D. 2000a. "The Causes of Corruption: A Cross-National Study." Journal of Public Economics 76, 399-457.

Treisman, D. 2000b. "Decentralization and the Quality of Government." International Monetary Fund Working Papers. Available at http://www.imf.org/external/pubs/ft/seminar/2000/fiscal/treisman.pdf (last accessed 27 December 2012).

Volejníková, J. 2007. Korupce v ekonomické teorii a praxi. Zelenec: Profess Consulting pp. r. o.

Vörös, L. 2011. "Úvod: Korupcia ako historický fenomén." Forum Historiae 5(2), 1-13. 
Wang, Y. 2013. "Court Funding and Judicial Corruption in China." China Journal $69,43-63$.

Act no. 300/2005. Criminal Code.

Zemanovičová, D. 2002. "Ekonomické aspekty korupcie." Ekonomický časopis 50(2), 182-196.

Zemanovičová, D., E. Sičáková and P. Ondrejka. 2001. Volnost' v rozhodovaní ako zdroj korupcie. Bratislava: Vico - vydavatelstvo. 